\title{
The Rate of Regeneration of Native Plant Species After Eradication of Invasive Alien Plant Species (Acacia Decurrens Willd.) in the Limpopo Province, South Africa.
}

Melford Mbedzi ( $\nabla$ melford.mbedzi@gmail.com )

University of Venda

Milingoni Peter Tshisikhawe

University of Venda

Sebataolo Rahlao

South African National Biodiversity Institute

Innocent Ndidzulafhi Sinthumule

University of Johannesburg

\section{Research Article}

Keywords: Acacia decurrens, Recolonization, Invasive alien plants, Restoration, Eradication, Native plant species

Posted Date: March 22nd, 2021

DOI: https://doi.org/10.21203/rs.3.rs-294036/v1

License: (c) (i) This work is licensed under a Creative Commons Attribution 4.0 International License.

Read Full License 


\section{Abstract}

Riparian invasive alien plants are known to compete with native plant species for water, space, daylight, and different other resources by decreasing structural diversity of native vegetation and subsequently changing the functioning of the ecosystem. The aim of this study was to investigate the rate of native plant species recolonization after the eradication of $A$. decurrens. The investigation was done in the Waterberg District Municipality, Limpopo Province in a farm, which is highly infested with $A$. decurrens. Twenty-four permanent plots of $10 \mathrm{~m} \times 10 \mathrm{~m}$ were constructed and the $A$. decurrens individuals in the plots were removed and the area was monitored for a period of 2 years. The size of quadrats was based on the size and distribution of the invasive alien plants which develop in an aggregated form and have exceptionally small canopies.

\subsection{Introduction}

About 250 thousand acres of wattle trees are propagated for commercial purposes in the Union of South Africa, primarily for the wattle bark, or its extract, which have valuable tanning properties. The bark reaches maturity when the trees are from eight to ten years of age and the timber is used in the gold mining industry and as fuel. Two species of wattle, originally introduced from Australia where they are indigenous, are grown commercially from natural seed; green wattle, Acacia decurrens Willd., and black wattle. A. mollissima Willd. The growth of $A$. decurrens wattle is mostly thought of as being superior to $A$. mollissima under unfavourable conditions in South Africa, however, as a result of its bark containing an excessive amount of red colouring matter, the tiny proportion of A. decurrens in cultivation is slowly disappearing in favour of A. mollissima.

The environmental and financial effect caused by invasive species on native plants in Australia is not broadly reported by barely any contextual investigations, notwithstanding increasing awareness of the potential of indigenous plants as weeds. The effects of invasive alien plant can incorporate disturbance to environmental cycles by sped up biomass accumulation, decreased light infiltration, increased nitrification, changed fire intensity and frequency, altered geo-morphological processes, hybridisation with congeners, which can prompt decreases in the richness of species and diversity. A large number of these effects are like the attack of plants beginning from different nations (alien plants). Nonetheless, measured effect data on biodiversity esteems are only distributed for Pittosporum undulatum Vent. (Mullett and Simmons, 1995; Rose and Fairweather, 1997), Leptospermum laevigatum (Sol. ex Gaertn.) F. Muell. (Lam and van Etten, 2002) and Acacia longifolia (Andrews) Willd.

The environmental effects of Australian invasive plants, particularly acacias, are the most contemplated species in South Africa, it was discovered that thirteen of these plant species are currently naturalized, and eight of these plants cause far reaching alteration of biological communities and ecological systems (Richardson and van Wilgen, 2004). While a comparable size of infestation and effects are still to be revealed from indigenous acacias in Australia, indirect proof demonstrates that the potential is there. Vigorous population growth of $A$. Iongifolia, A. dealbata Link, $A$. pycnantha Benth. and A. decurrens Willd. 
in Western Australia; A. cyclops Cunn. ex Don in South Australia; and A. saligna (Labill.) W.L. Wendl., A. baileyana F. Muell. and A. Iongifolia in eastern Australia indicate broad-scale impacts could also be inevitable if there is no implementation of acceptable management measures

As invasive native plants are increasingly recognised as problematic in natural vegetation (Adair, 2008) many are subject to suppression programs to protect biodiversity values. Control options vary according to life-form, susceptibility, risk of non-target damage, ease of implementation, size of infestation and outcome targets. Control choices for indigenous plants incorporate the utilization of herbicides, managed fire, grazing, mechanical eradication, biological control, and coordinated strategies, including the profoundly viable technique (for some woody plants) of 'rolling' infestation with substantial equipment, then using fire after a time of drying (Muyt, 2001).

\subsubsection{Occurrence of species under study}

\subsubsection{Acacia decurrens}

Acacia decurrens is indigenous to plateaus of Victoria and New South Wales and temperate littoral to inland zones that are cool but not to xeric or hot regions of inland New South Wales. It occurs in high precipitation zones with $600-1,400 \mathrm{~mm}$ per year and is generally tolerant to a wide range of environments. In forests and xeric sclerophyll forests in New South Wales, it establishes with plants such as Eucalyptus punctata and small leaved Eucalyptus crebra (Benson and McDougall, 2001). In territories where it has become naturalised, Acacia decurrens is commonly found along the roads, creek lines and in wasteland areas. It also develops in disturbed locations adjacent to bushlands and open forests (Benson and McDougall, 2001). It was broadly propagated in New South Wale, and it is hard to tell whether it is indigenous or naturalised in zones close to its native rangelands.

\subsection{Methodology}

The study was conducted in the Waterberg district municipality which is found in the north west of Mookgophong town and highly infested with Acacia decurrens. It lies at 24.22'S and 28.46'E. As shown in figure 1, the Waterberg district municipality is one of the five district municipalities of Limpopo Province in South Africa. The area is mainly dominated by Northern Sotho and Afrikaans speaking people. The population of Acaciadecurrens was distributed along the stream which passes through the farm. It receives summer rainfall, and the vegetation is that of a Savanna biome and includes species such as Combretum molle, Themeda triandra, Setaria sphacelata, Terminalia sericea and Burkea africanum.

Twenty-four permanent plots of $10 \mathrm{~m}$ x $10 \mathrm{~m}$ each were constructed along the riparian zone using iron bars as corner posts. The choice of the size of the quadrat was made after assessing the morphology and distribution of invasive alien species under study. The number of alien invasive species and native species present in quadrats were recorded before they were removed. Invasive alien plant species were 
removed mechanically. No chemicals were used since there are concerns about their adverse environmental implications. The areas were monitored for the re-establishment of alien invasive species so that they could be removed when they reoccur. Only native plant species were left alone once they establish themselves in the study site. All data collected were entered and stored in Microsoft Excel 2010, which were also used in the descriptive statistical analysis of the results. They were then analized using Primer V6 and PERMANOVA.

Figure 2 shows a population of the wattle which re-sprouted a few months after the fire which occurred on the site which had dry trees felled by the personnel from the 'Working for Water' program. The trees were cut in June 2015 and by December the same year, a fire of high intensity occurred due to the litter from fallen trees.

\subsubsection{Description of the species under study}

\subsubsection{Acacia decurrens}

Acacia decurrens is indigenous to the New South Wales where it is found primarily on the coast and plateau from the Hunter Valley south to the Australian Capital Domain. This distribution is outside the target region, however, not a long way from its eastern border. Acacia decurrens has been widely cultivated as an ornamental species and has turned out to be naturalized in numerous regions, both within Australia and abroad. In Australia, acclimatized individuals are found in southwest Western Australia, southeast South Australia, and southeast Queensland, parts of New South Wales, the Australian Capital Domain, Victoria and Tasmania. Kodela and Tindale (2001) provided maps of both the natural and naturalized distributions. Presently, conventional wattle orchards cover 130000 ha in the KwaZulu-Natal and Mpumalanga areas. The species is very invasive by its nature (Figure 3). It reproduces large number of hard-covered seeds which are generally long-lived and are spread rapidly down water bodies and across the activity of soil. Invasions are in all zones in South Africa where the annual precipitation surpasses $500 \mathrm{~mm}$. The province normally influenced are the Western Cape, Eastern Cape, KwaZulu-Natal and Mpumalanga, however parts of provinces like Free State, Gauteng and Limpopo are likewise influenced (De wit et al., 2001).

\subsubsection{Establishment}

Acacia decurrens can be effortlessly grown from seeds but, similarly as with many acacias, the seeds must undergo some pre-treatment to promote germination. The best strategy is to heat the seeds at $100^{\circ} \mathrm{C}$ for 1 minute in a relatively vast volume of water (Richardson et al., 2015). The seeds must then be allowed to cool and consume water for 24 hours. Seeds that float to the surface are mostly not potent and ought to be disposed of while viable seeds ought to swell and sink. The seeds can likewise be shaken (Wrigley and Fagg, 1996) and mechanical scratching of the seed coat is an alternative. The 
average viability of $A$. decurrens seeds, considering laboratory tests of 12 provenances, is 57000 seeds for every kilogram and optimum temperature for ideal germination is $25^{\circ} \mathrm{C}$. Germination starts after five days and every viable seed generally develops within 25 days (Richardson et al., 2015).

\subsubsection{Impacts}

There are numerous effects related with black wattles in South Africa. A considerable lot of these emerge from formal plantations, yet a few (such as fuel wood, charcoal and materials for building) may be derived from sites of invasion. There are different kinds of negative effects that can be ascribed to both wattle estates and invasion, for instance; it affects both lower surface overflow and water accessibility, and effect on biological diversity (De wit et al., 2001).

\subsection{Results}

\subsubsection{Species Richness}

Significant difference in species richness was observed between the sampling periods. The observations of the eradicated sampling plots showed that species richness in the dug area of Acacia decurens was found to be 09 (Sep-2016) before eradication and 15 (Jun-2017), 11 (Sep-2017), 21 (Dec-2017) and 13 (Mar-2018) post eradication (Table 1).

\section{Table 1}

Floral species richness during the sampling periods following eradication of Acacia decurens

\begin{tabular}{|lllllll|}
\hline Response variable & Treatment & Sep-2016 & June-2017 & Sep-2017 & Dec-2017 & Mar-2018 \\
& & & & & & \\
Species richness & Digging & 09 & 15 & 11 & 21 & 15 \\
\hline
\end{tabular}

Significant decrease in number of $A$. decurens was accompanied by a significant increase in number of other species (Table 1, Figure 4). Highest number of the other species were observed during the same period as the lowest number of $A$. decurens (2017-Dec).

The MDS plot of species composition clearly indicated the different in species richness between the sampling periods (Figure 5). More species are observed in 2017-Dec, which is like what is presented on species richness table (Table 1). The similarity between the sampling periods was primarily attributed to species such as $A$. decurens, Cleome, B. pilosa and S. pinnata which were the dominant plant species among the quadrants during the sampling periods.

\subsubsection{Frequency}


The five sampling periods hosted different species before and after digging. Frequency was high after the eradication of $A$. decurens (Table 2). There was an increase of six species (Cleome sp, Mupatsapatsane, Digitaria sp, Schkurhia pinnata, Purple sp, Hibiscus cannabis, Bidens pilosa, Sida cardifolia, D. liquidios and Congesta). This was because when $A$. decurens was dug, new species were observed with only $A$. decurens observed during all the sampling periods, followed by S. cephaselata, Cleome, S. pinnata and B. pilosa observed during four of the sampling periods. These species are the ones that seem to be able to resist or compete with $A$. decurens.

\section{Table 2}

Frequency of native plant species following eradication of Acacia decurens 


\begin{tabular}{|c|c|c|c|c|c|}
\hline Species name & $\begin{array}{l}\text { 2016- } \\
\text { Sep }\end{array}$ & $\begin{array}{l}\text { 2017- } \\
\text { Jun }\end{array}$ & $\begin{array}{l}\text { 2017- } \\
\text { Sep }\end{array}$ & $\begin{array}{l}\text { 2017- } \\
\text { Dec }\end{array}$ & $\begin{array}{l}\text { 2018- } \\
\text { Mar }\end{array}$ \\
\hline Acacia decurens & 100 & 100 & 100 & 66.666 & 100 \\
\hline Eragrostis sp & 100 & 0 & 83.333 & 0 & 0 \\
\hline Seteria cephaselata & 33.333 & 16.666 & 33.333 & 0 & 100 \\
\hline Andropogon sp & 16.666 & 0 & 0 & 0 & 0 \\
\hline Diospyros lycioides subsp lycioides & 16.666 & 0 & 16.666 & 0 & 0 \\
\hline Cynadon dactylon (L.) Pers & 16.666 & 33.333 & 0 & 33.333 & 0 \\
\hline Cleome sp & 0 & 100 & 50 & 100 & 100 \\
\hline Squirossa & 33.333 & 0 & 0 & 0 & 0 \\
\hline $\begin{array}{l}\text { Hyparrhenia hirta (L.) } \\
\text { Stapf }\end{array}$ & 16.666 & 50 & 16.666 & 0 & 0 \\
\hline Mupatsapatsane & 0 & 16.666 & 0 & 0 & 0 \\
\hline Lippia javanica (Burm.f.) Spreng & 0 & 0 & 0 & 0 & 16.666 \\
\hline Maximellum & 33.333 & 0 & 0 & 0 & 0 \\
\hline Digitaria $s p$ & 0 & 83.333 & 0 & 16.666 & 33.333 \\
\hline Schkurhia pinnata & 0 & 66.666 & 50 & 33.333 & 33.333 \\
\hline Purple $s p$ & 0 & 16.666 & 0 & 0 & 0 \\
\hline Hibiscus cannabis & 0 & 100 & 0 & 16.666 & 0 \\
\hline Bidens pilosa & 0 & 66.666 & 33.333 & 100 & 100 \\
\hline Amaranthus spinosa & 0 & 0 & 0 & 0 & 33.333 \\
\hline Corchorus tridens & 0 & 0 & 0 & 16.666 & 0 \\
\hline Hypoxis hermirocallidae & 0 & 0 & 0 & 16.666 & 0 \\
\hline Mutomane & 0 & 0 & 0 & 16.666 & 0 \\
\hline E. panides & 0 & 0 & 0 & 16.666 & 0 \\
\hline Panicum coloratum & 0 & 0 & 0 & 33.333 & 0 \\
\hline Sida cordifolia & 0 & 16.666 & 0 & 0 & 33.333 \\
\hline D. liquidios & 0 & 66.666 & 33.333 & 66.666 & 0 \\
\hline Congesta & 0 & 16.666 & 0 & 0 & 0 \\
\hline Serge sp & 0 & 16.666 & 0 & 16.666 & 0 \\
\hline
\end{tabular}




\begin{tabular}{|llllll|} 
Sp1 & 0 & 0 & 50 & 33.333 & 66.666 \\
\hline A. fracntico & 0 & 0 & 50 & 33.333 & 0 \\
\hline Sambucus Canadensis & 0 & 0 & 0 & 16.666 & 0 \\
\hline Eschscholzia califonica & 0 & 0 & 0 & 16.666 & 0 \\
\hline Asparagus sp & 0 & 0 & 0 & 33.333 & 0 \\
\hline Sporobolus & 0 & 0 & 0 & 33.333 & 100 \\
\hline D. singuinalis & 0 & 0 & 0 & 16.666 & 0 \\
\hline P. patens & 0 & 0 & 0 & 16.666 & 0 \\
\hline H. sativum & 0 & 0 & 0 & 0 & 16.666 \\
\hline Tshinukhwa & 0 & 0 & 0 & 0 & 16.666 \\
\hline Dispiros sp & 0 & 0 & 0 & 0 & 16.666 \\
\hline
\end{tabular}

The two figures above (Figure 6 (a) and (b)) are showing the study site after two different events had occurred. In Figure 6 (a) A. decurrens litter, after the people from the 'Working for Water' Programme had cut some and ring-barked some of the trees and applied the chemicals. This was before the fire occurred and burnt all the litter and (b) the study site just after the fire which was said to have occurred accidentally in December 2015.

Figure 7 (a) shows part of the study site few weeks after the fire occurred, (b) shows numerous seedlings germinating on the study site just few weeks after the fire which removed the litter left by the people from the WfW programme after removing the invader, (c) shows the study site colonized by grasses and small herbaceous plants after 12 months monitoring the area and (d) shows the trees found adjacent to the study site showing $A$. decurrens monopolizing the area which was not monitored.

No grasses or any other plant species were seen growing in the same vicinity as $A$. decurrens except for other invader plant species such as the Eucalyptus. After the eradication, grasses started to colonize the area (Figure 7).

Some of the herbaceous species that occupied the area disappeared during the study, but these grasses remained persistent throughout. This area was covered with only an impenetrable layer of $A$. decurrens plant species before the experiment was conducted (Figure 8).

\subsection{Discussion}

The fundamentally lower native species spread for controlled sites is the same with other different investigations where invasive alien vegetation was eradicated from riparian zones (Harms and Hiebert, 
2006; Galatowitsch and Richardson, 2005). As anticipated, the reference zones had less invasive alien species spread than infested and controlled regions. The lower native species spread inside controlled sites was influenced by the presence of alien species. Since the investigation assessed the early recuperation of species ( 1 to 4 years), it is foreseen that the moderate establishment of riparian species that have endured invasion and control will increase their spread as time advances. Much of the time, restoration of invasive alien invaded riparian vegetation in South Africa is genuinely crude and its objective is basically to return key components of ecosystem functioning. This investigation indicated that there is potential for self-repair, even in regions that have been intensely infested. Not all components normally return unaided. These regions need re-introduction of species to complete the restoration procedure. The benefit of maintaining a seed source for the woody, animal-dispersed riparian species cannot be neglected (Wassie and Teketay, 2006). It is proposed that in localities where such seed sources are inadequate with regards to re-introductions through planting, propagated specimens ought to be a part of the post-disturbance restoration process. Without this fundamental step, restoration is probably going to be fruitless, and may result in the re-establishment of invasive alien plants (Vosse et al., 2008).

Herbaceous and grass species were seen colonizing the study site after the clearing of alien invasive plant species. The brief timeframe of this investigation makes it hard to completely investigate the seral (changes in species composition through time) changes in the native vegetation. The significant fact with respect to the restoration of post-clearance is that recolonization of vegetation is generally by native species instead of the unpleasant condition of complete secondary invasion by the same or other alien species. Where clearing of invasive alien plant species was not performed, there was no establishment by any other plant species except for Acacia decurrens.

This demonstrates that $A$. decurrens affects the indigenous plant populations recovery, as it hinders their existence in its vicinity. However, the large amounts of discovered total native re-establishment shows that the mechanism demonstrates a very important level of flexibility to disturbance by invasive alien plants. Flexibility is explained as the capacity of a vegetation to recover to its previous condition after a disturbance or pressure (Wali, 1999). Numerous riverine species are naturally flexible because of regular and severe disturbance (Richardson et al., 2007) and have distribution and formation mechanisms, for example, the capacity to colonize virgin landscape and hostile clonal development that allows for quick recuperation following a disturbance (Naiman and Decamps, 1997). Continued monitoring and eradication of invasive alien plants by 'Working for Water' programme is a vital component that equips this flexibility in the mechanism, as the repetitive clearing exhausts the invasive alien species seed pools and keeps invasion at levels that are generally easier to control provided it is done before they reach reproductive stage.

More than 1000 native plant species are pressurized by invasive alien species (Raimondo et al., 2009), and if invaders somehow managed to achieve total degree of their possible dissemination, the total biological diversity in the Cape floristic region (CFR) could be lowered by an estimated $40 \%$ (Van Wilgen et al., 2008). The greater part of the regions' watersheds exists in protected zones, where progressing invasion by trees and bushes is compromised, thereby decreasing surface water overflow by as much as 
$36 \%$ (whenever permitted to achieve the full degree of their possible dissemination), with significant financial effects (Van Wilgen et al., 2008). Considering worries about the loss of water reservoirs and biological diversity, the South African Department of Water Affairs initiated an expansive programme to cut weeds in 1995.

This programme 'Working for Water' which works nationwide and inside the Cape Floristic Region (CFR), gives funding to the control of invasive alien plants both within and outside the protected regions. In sites where the programme has been active in the CFR, there are signs that the site infested by invasive plants has been lowered by practically half (McConnachie et al., 2016). However, the program has just achieved a little amount (4-13\%) of the total infested region (Van Wilgen et al., 2012). At the CFR's scale of protected regions, there has been no endeavour up to so far to precisely measure the size of the issue, or the expense of management, nor has it been conceivable to evaluate advancement regarding lowering the infestation because of the shortage of a follow-up observation scheme (Van Wilgen and Wannenburgh, 2016).

\subsection{Conclusion And Recommandations}

This study indicates that much can be learned about the success and direction of the recolonization path at an early-stage of restoration. In order to correct ecosystems that are either recovering slowly or are going in a different direction off the desired recolonization path, early-stage evaluations must be conducted to gain insight into the status and path that the recolonization project is currently on.

At early-stages of recolonization, success is mostly dependent upon the survival and establishment of native vegetation, either through (active restoration) plantings or (passive restoration) natural regeneration and is therefore largely dependent on the management techniques used to promote ecosystem recovery. Longer-term success is dependent on the status of earlier-stage recolonization results, the application of ongoing management techniques, and the presence (or absence) of further ecosystem disturbance. Although complete success is yet to be determined, evaluating early-stage results provide a chance for midcourse correction, where unsuccessful recolonization can be sped up or steered back on track by altering management techniques and on-site ecosystem conditions.

In conclusion, from the results obtained during the investigation, it is possible for recolonization by indigenous plant species to occur in the regions previously infested with invasive alien plant species such as Acacia decurrens, though follow-up monitoring of the controlled areas needs to be practiced after the eradication of invasive alien plant species.

\section{References}

1. Adair, R.J., 2008. Biological control of Australian native plants, in Australia, with an emphasis on acacias. Muelleria, 26(1), pp.67-78. 
2. Benson, D. and McDougall, L., 2001. Ecology of Sydney plant species. Part 8. Dicotyledon families Rutaceae to Zygophyllaceae. Cunninghamia, 7(2), 241-462.

3. De Wit, M.P., Crookes, D.J. and Van Wilgen, B.W., 2001. Conflicts of interest in environmental management: estimating the costs and benefits of a tree invasion. Biological invasions, 3(2), 167178.

4. Galatowitsch, S.M. and Richardson, D.M., 2005. Riparian scrub recovery after clearing of invasive alien trees in headwater streams of the Western Cape. Biological Conservation 122, 509-521.

5. Cooper, D.C., 1936. Chromosome numbers in the Leguminosae. American journal of botany, pp.231233.

6. Harms, R.S., and Hiebert, R.D., 2006. Vegetation response following invasive Tamarisk (Tamarix spp.) removal and implications for riparian restoration. Restoration Ecology 14, 461-472.

7. Kodela, P.G. and Tindale, M.D., 2001. Acacia dealbata subsp. subalpina (Fabaceae: Mimosiodeae), a new species from south-eastern Australia. Telopea 9:319-32.

8. Koenig, R., 2009. Unleashing an army to repair alien-ravaged ecosystems. Science 325, 562-563.

9. Lam, A. and van Etten, E., 2002. Invasion of indigenous vegetation in south-western Australia by Leptospermum laevigatum (Myrtaceae). In Proceeding of the 13th Australian Weeds Conference pp. 545-548.

10. McConnachie, M., Van Wilgen, B.W., Ferraro, P.J., Forsyth, A.T., Richardson, D.M., Gaertner, M. and Cowling, R.M., 2016. Using counterfactuals to evaluate the cost-effectiveness of controlling biological invasions. Ecological Applications 26, 475-483.

11. Mullett, T. and Simmons, D., 1995. Ecological impacts of the environmental weed sweet pittosporum (Pittosporum undulatum Vent.) in dry sclerophyll forest communities, Victoria. Plant Protection Quarterly, 10(4), 131-138.

12. Muyt, A., 2001. Bush invaders of south-east Australia: a guide to the identification and control of environmental weed found in south-east Australia. R and FJ Richardson: Melbourne.

13. Naiman, R.J. and Décamps, H., 1997. The ecology of interfaces: Riparian zones. Annual Review of Ecology and Systematics 28, 621-658.

14. Newman, H.H., 1934. Dermatoglyphics and the problem of handedness. American Journal of Anatomy, 55(2), 277-322.

15. Raimondo, D., Van Staden, L., Foden, W., Victor, J.E., Helme, N.A., Turner, R.C., Kamundi, D.A. and Manyama, P.A., 2009. Red list of South African plants. Strelitzia 25. South African National Biodiversity Institute. Pretoria, South Africa.

16. Richardson, D.M. and Van Wilgen, B.W., 2004. Invasive alien plants in South Africa: How well do we understand the ecological impacts? South African Journal of Science 100, 45-52.

17. Richardson, D.M., Holmes, P.M., Esler, K.J., Galatowitsch, S.M., Stromberg, J.C., Kirkman, S.P., Pyšek, P. and Hobbs, R.J., 2007. Riparian zones degradation, alien plant invasions and restoration prospects. Diversity and Distributions 13, 126-139. 
18. Richardson, D.M., Le Roux, J.J. and Wilson, J.R., 2015. Australian acacias as invasive species: Lessons to be learnt from regions with long planting histories. Southern Forests: $A$ Journal of Forest Science 77(1), 31-39.

19. Rose, S. and Fairweather, P.G., 1997. Changes in floristic composition of urban bushland invaded by Pittosporum undulatum in northern Sydney, Australia. Australian journal of botany, 45(1), 123-149.

20. Van Wilgen, B.W. and Wannenburgh, A., 2016. Co-facilitating invasive species control, water conservation and poverty relief: Achievements and challenges in South Africa's Working for Water programme. Current Opinion on Environmental Sustainability 19, 7-17.

21. Van Wilgen, B.W., Forsyth, G.G. and Le Maitre, D.C., 2008. The prioritization of species and primary catchments for the purposes of guiding invasive alien plant control operations in the terrestrial biomes of South Africa. Unpublished report. CSIR Natural Resources and the Environment. Stellenbosch, South Africa.

22. Van Wilgen, B.W., Forsyth, G.G., Le Maitre, D.C., Wannenburgh, A., Kotzé, J.D.F., Van den Berg, E. and Henderson, L., 2012. An assessment of the effectiveness of a large, national scale invasive alien plant control strategy in South Africa. Biological Conservation 148, 28-38.

23. Vosse, S., Esler, K.J., Richardson, D.M. and Holmes, P.M., 2008. Can riparian seed banks initiate restoration after alien plant invasion? Evidence from the Western Cape, South Africa. South African Journal of Botany 74, 432-444.

24. Wali, M.K., 1999. Ecological succession and the rehabilitation of disturbed terrestrial ecosystems. Plant Soil 213, 195-200.

25. Wassie, A. and Teketay, D., 2006. Soil seed banks in church forests of northern Ethiopia: Implications for the conservation of woody plants. Flora-Morphology, Distribution, Functional Ecology of Plants, 201(1), 32-43.

26. Wrigley, J.W. and Fagg, M., 1996. Australian Native Plants: Propagation. Cultivation and Use in Landscaping, $4^{\text {th }}$ edition, Reed, Australia.

\section{Figures}




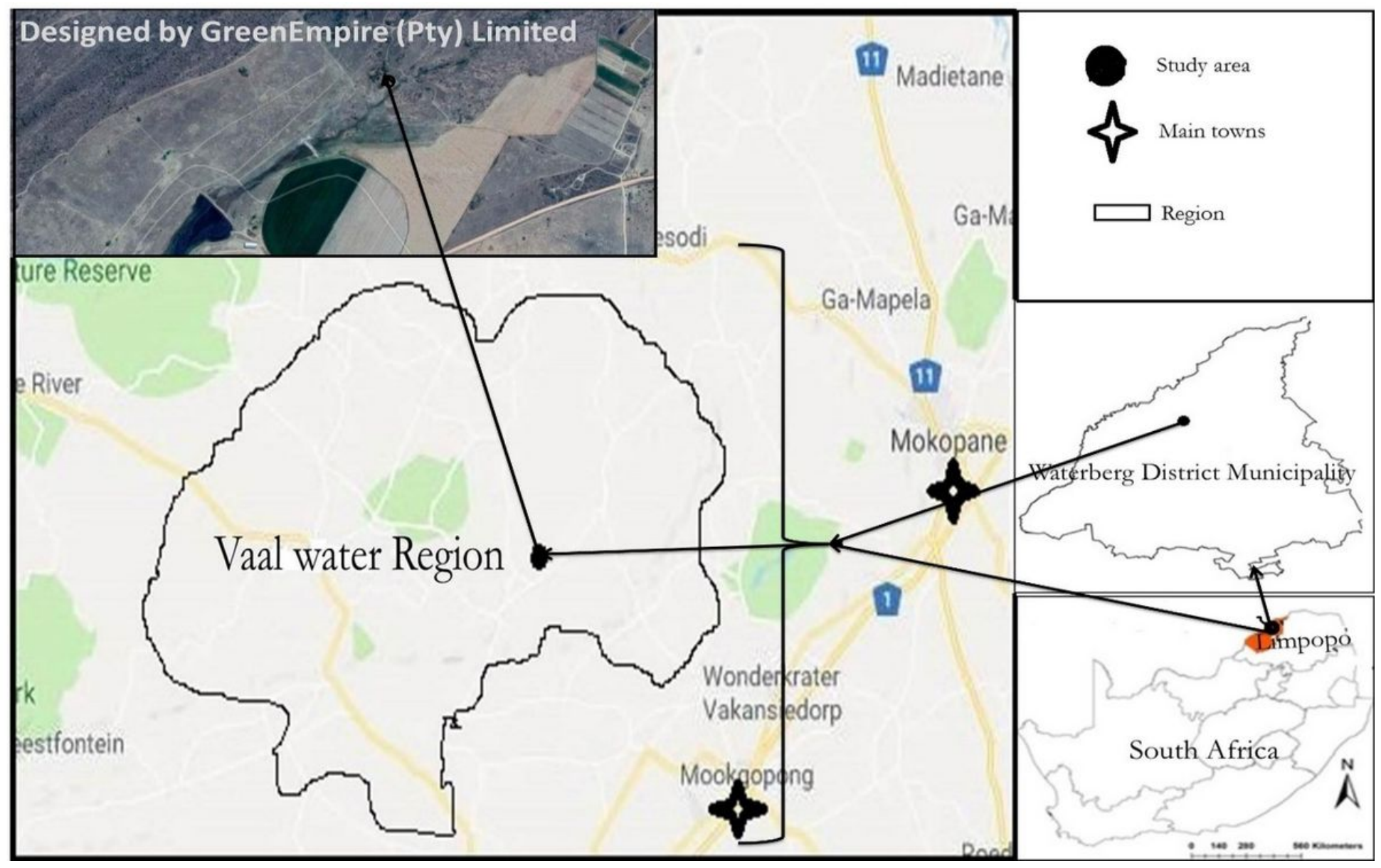

Figure 1

Map of the Waterberg District Municipality showing the study area in the Limpopo Province (Courtesy of the Green Empire (Pty) Limited) Note: The designations employed and the presentation of the material on this map do not imply the expression of any opinion whatsoever on the part of Research Square concerning the legal status of any country, territory, city or area or of its authorities, or concerning the delimitation of its frontiers or boundaries. This map has been provided by the authors. 


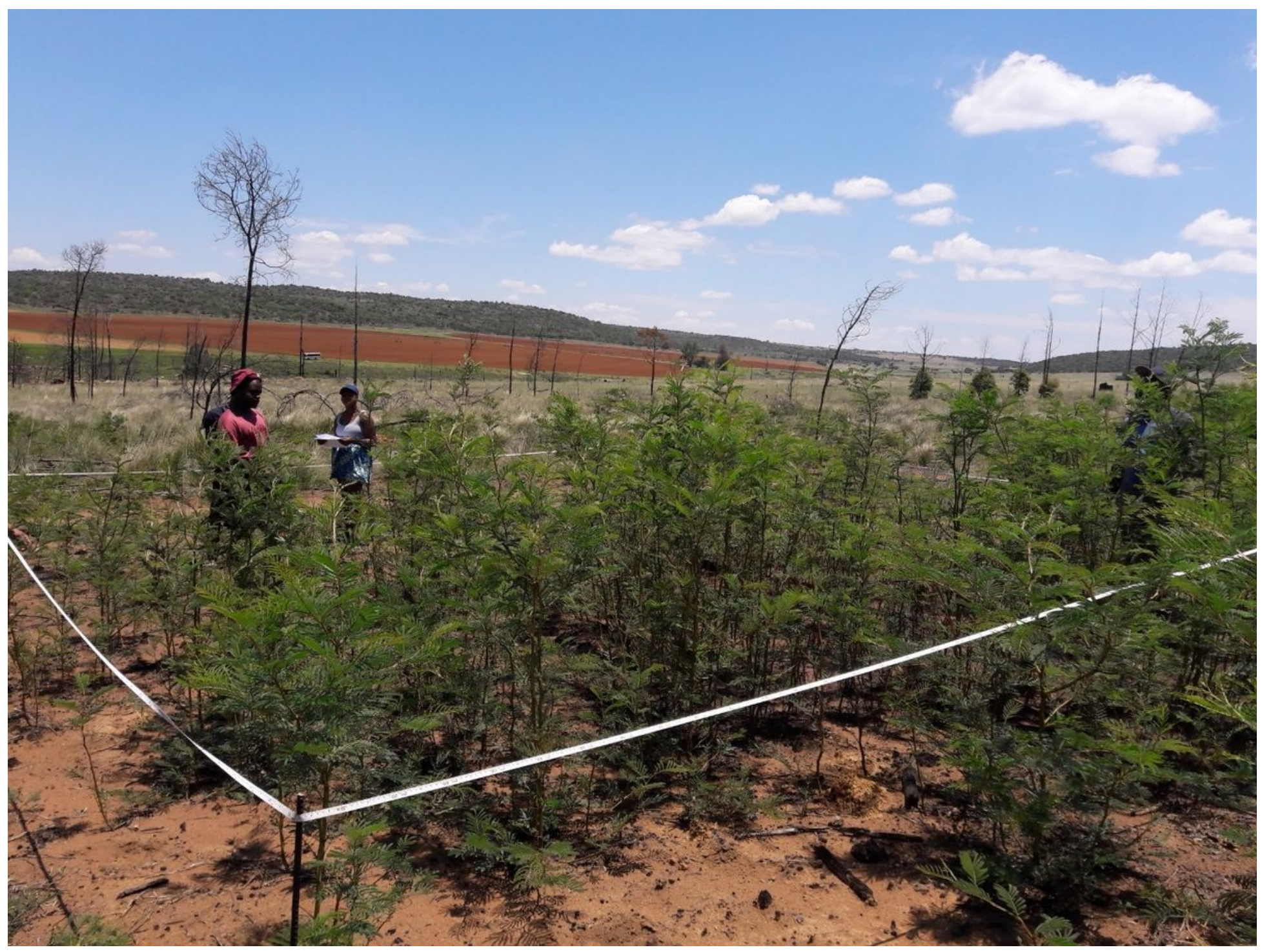

Figure 2

Picture showing the constructed quadrat in the Acacia decurrens population. 


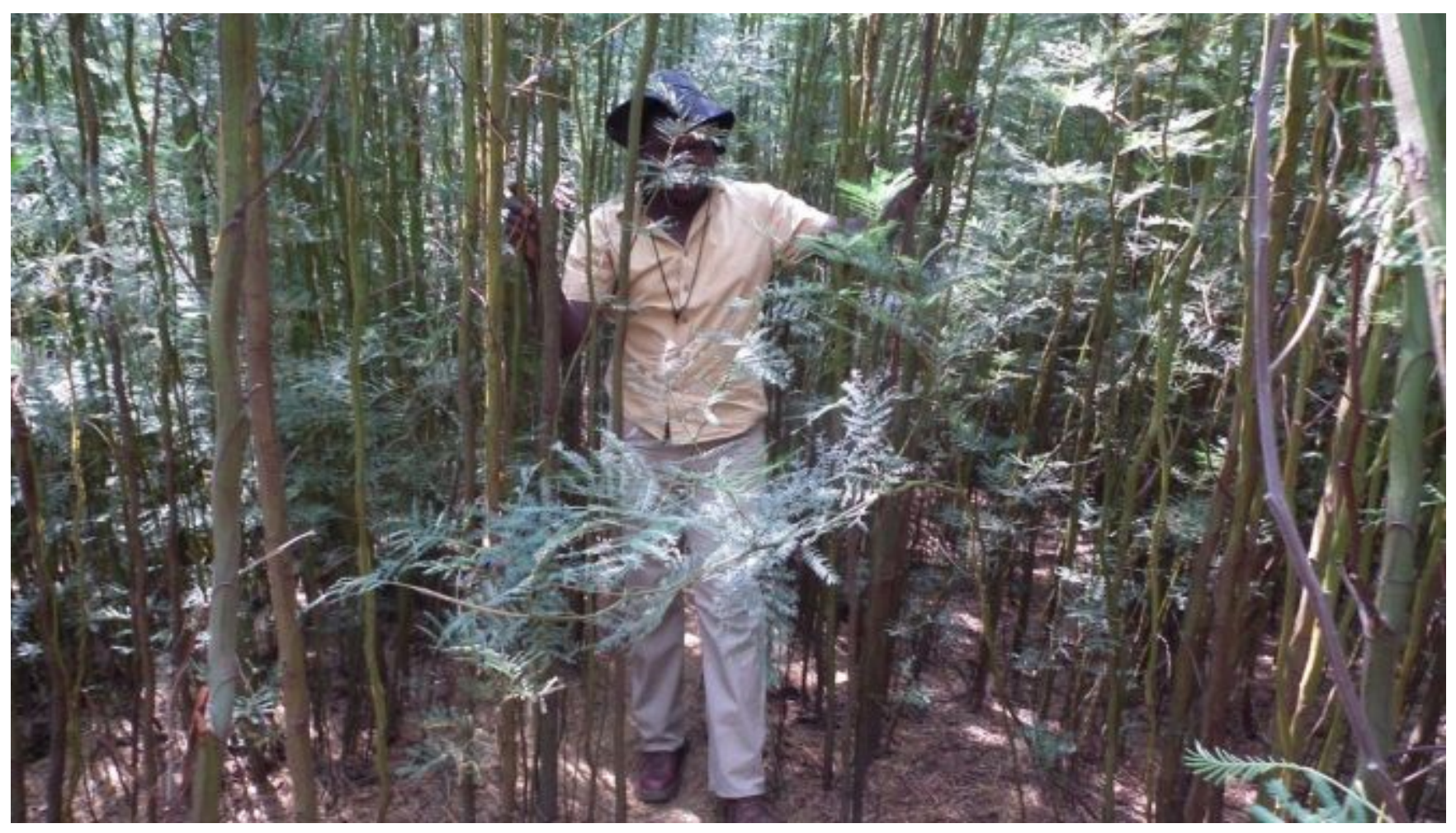

\section{Figure 3}

Picture showing a dense population of Acacia decurrens trees at the study site before initial clearing.

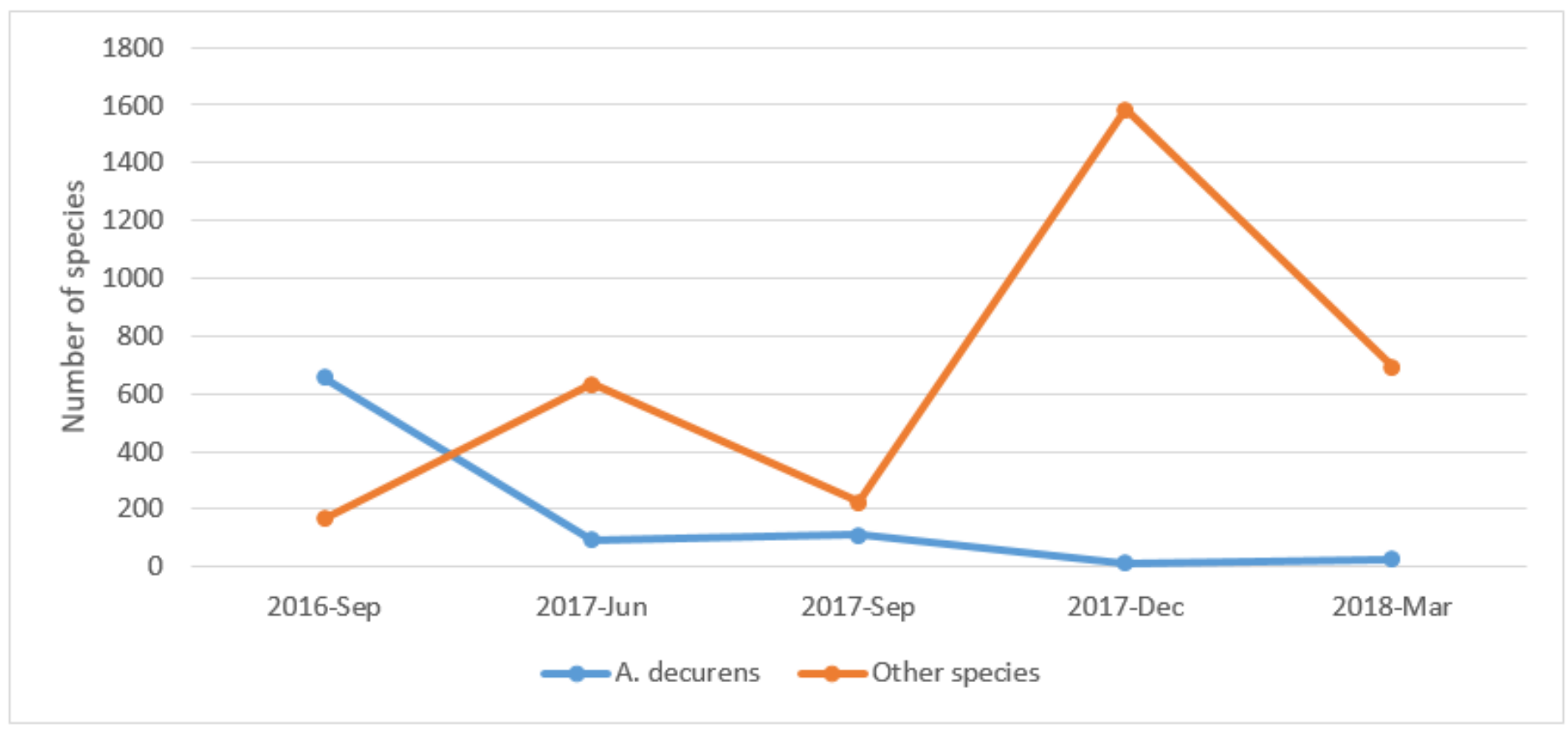

\section{Figure 4}

Line graph showing the number of Acacia decurens and other plant species pre (Sep-2016) and post digging. 


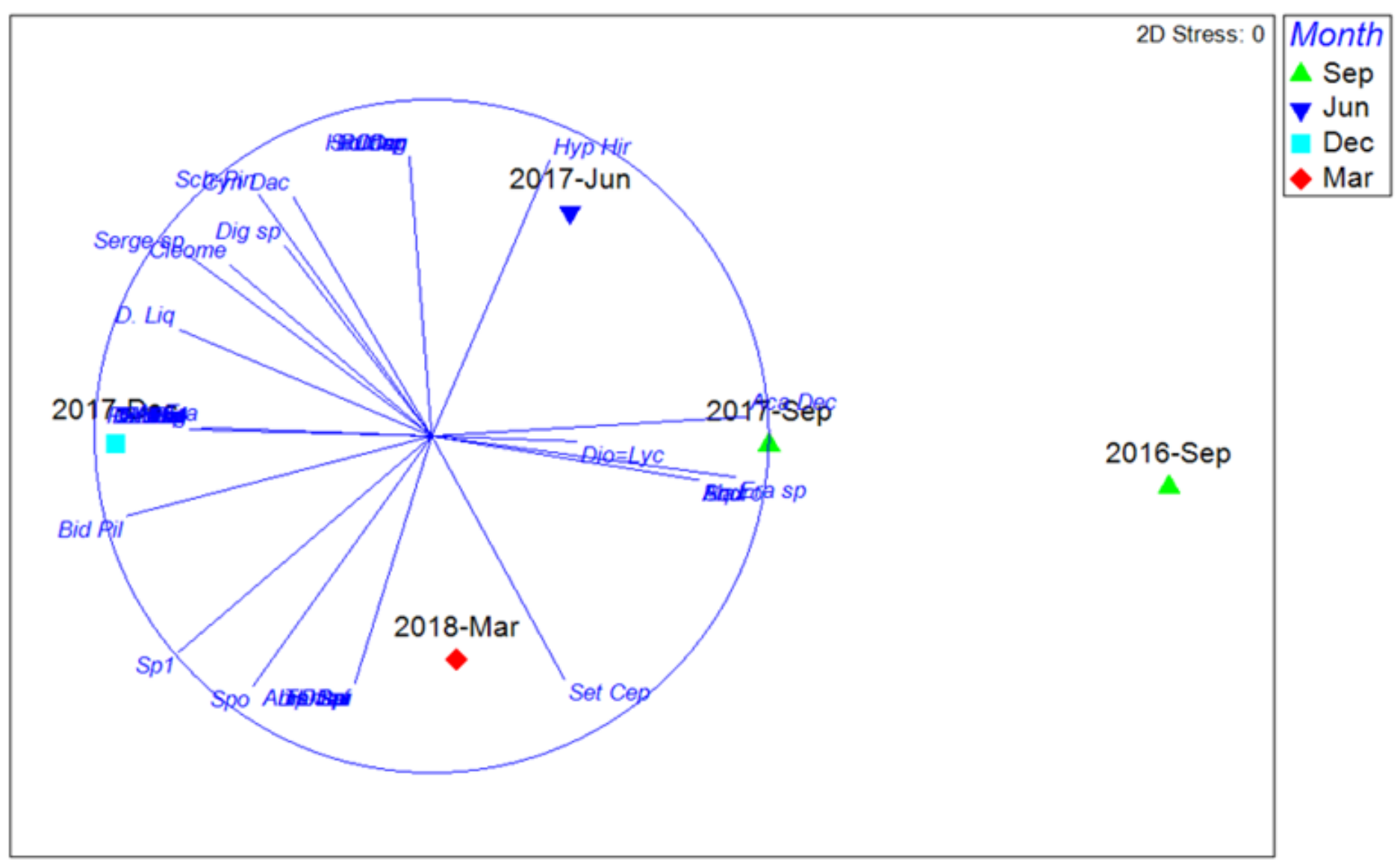

Figure 5

Multidimensional scaling ordination plots of species composition in different sampling periods between Sep-2016 and Dec-2017 following the eradication of Acacia decurens. 


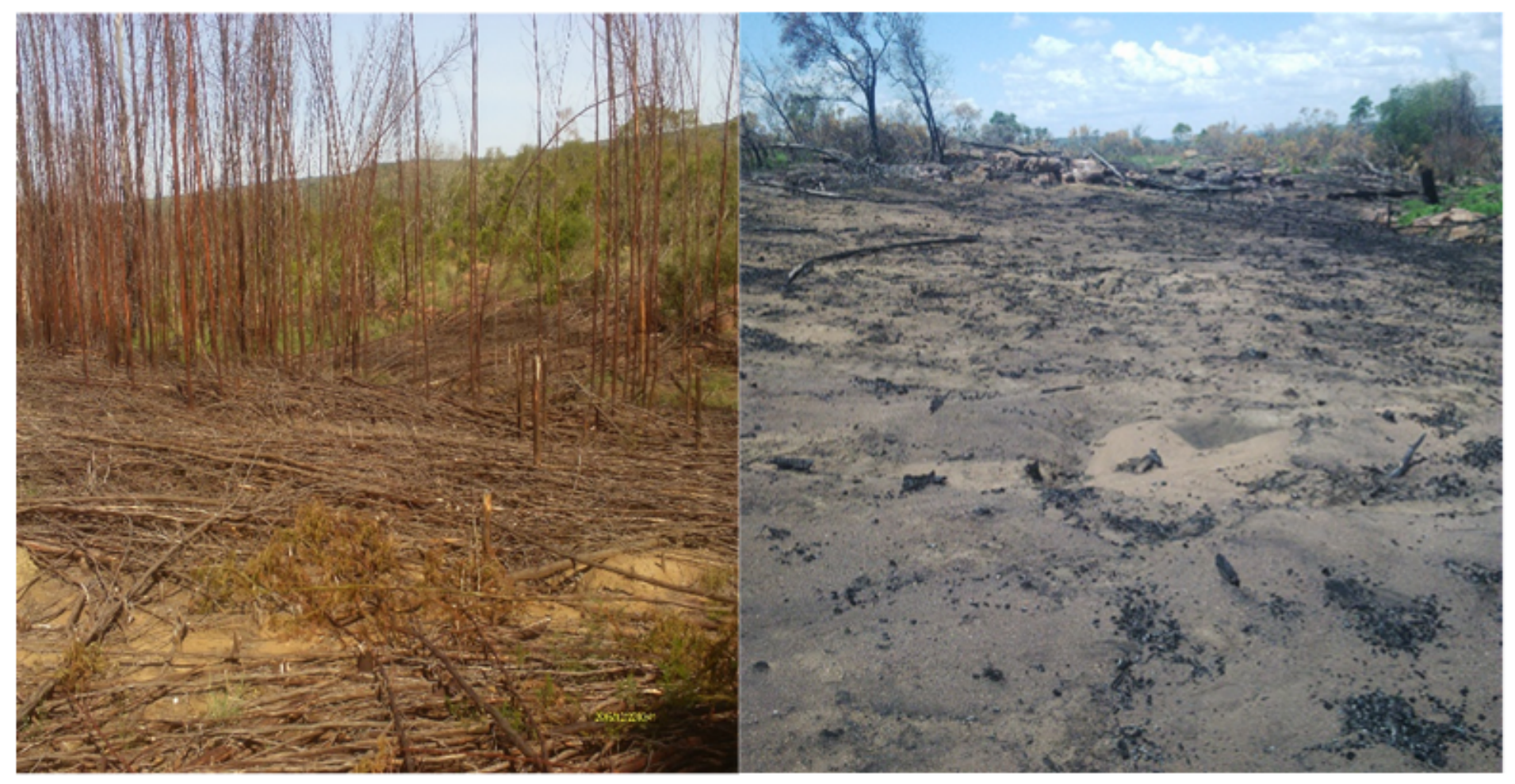

Figure 6

Study site with felled Acacia decurrens. 

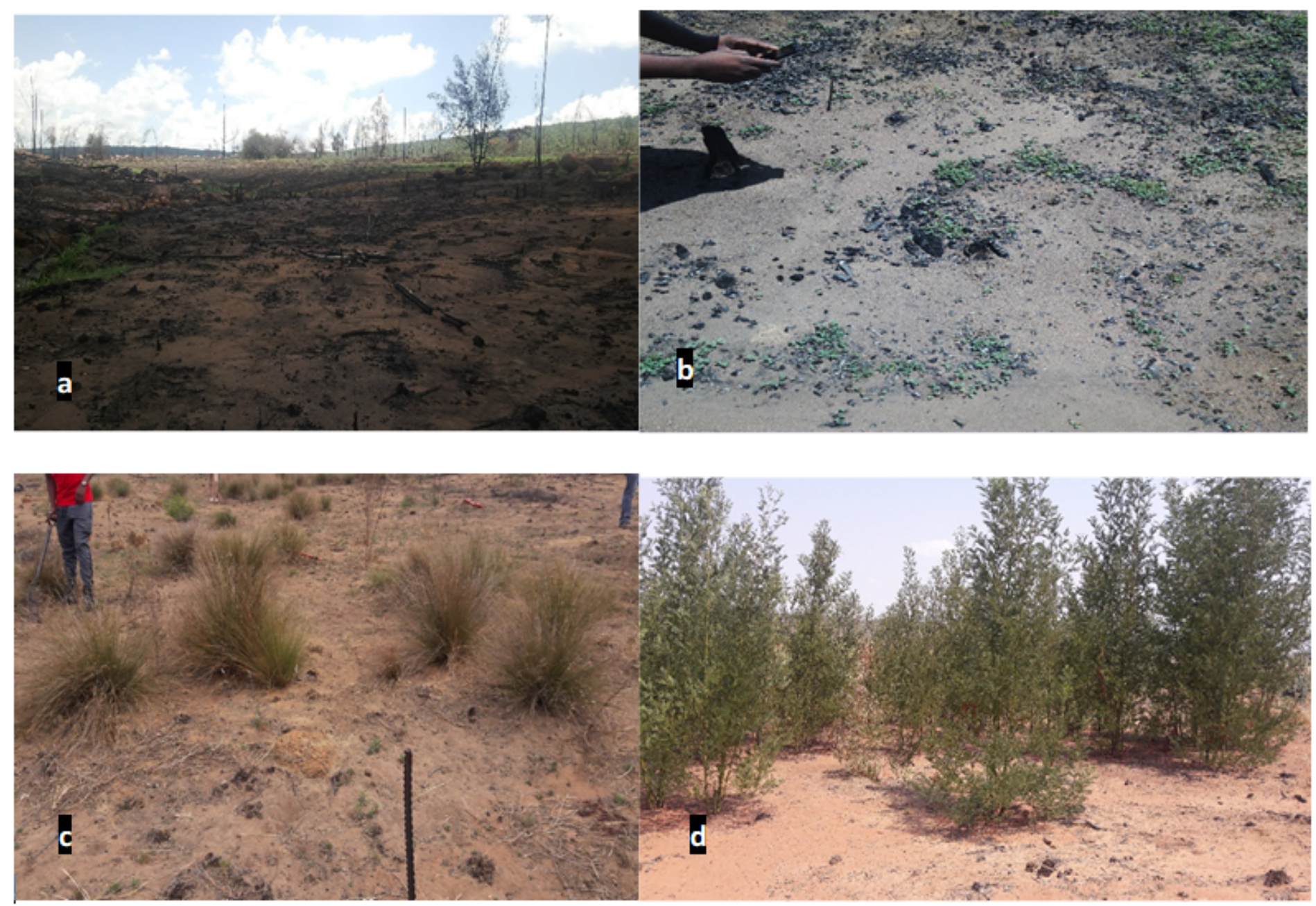

Figure 7

Some events at the study area. 


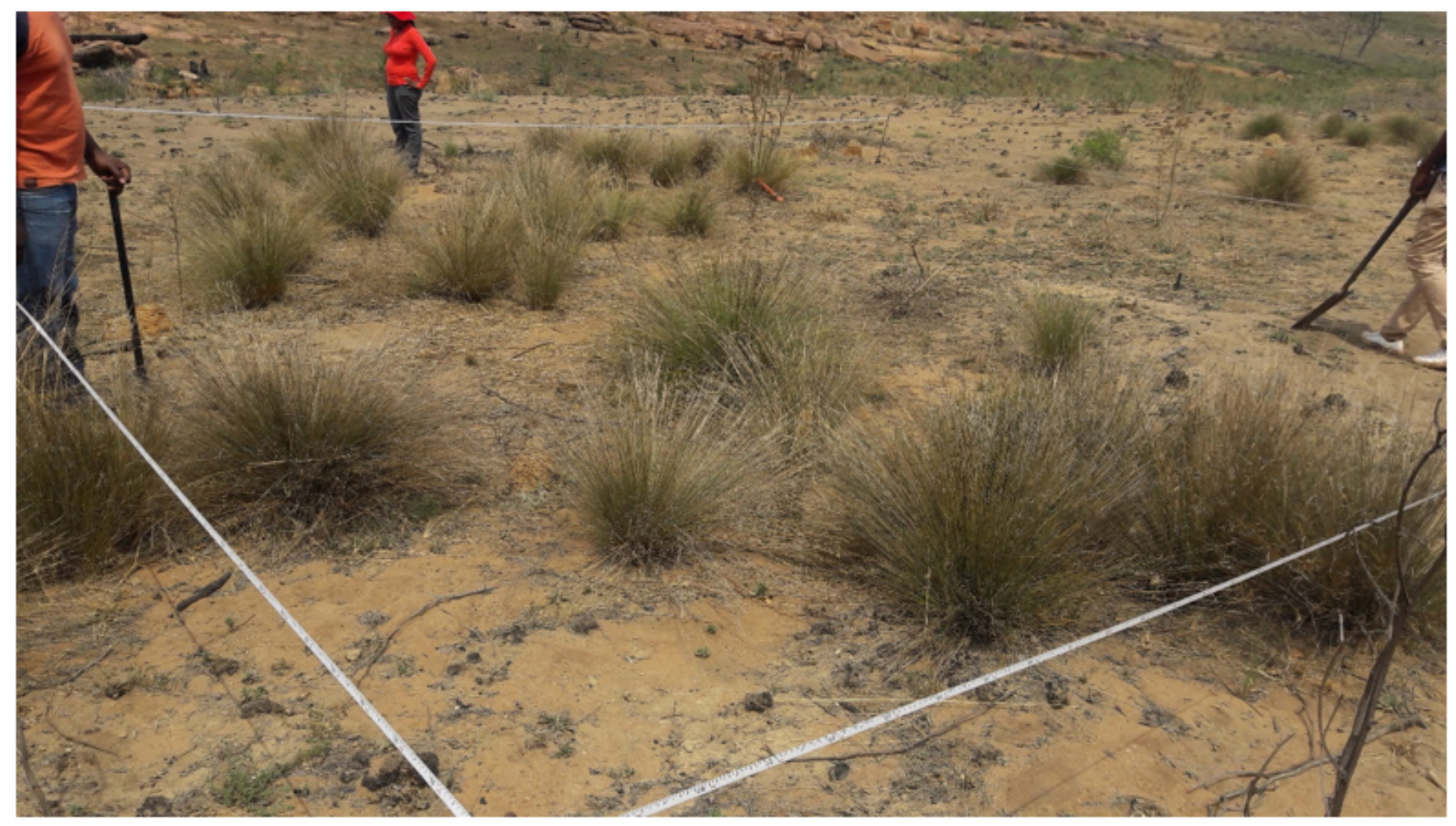

Figure 8

Grasses which colonized the area previously infested with Acacia decurrens trees 